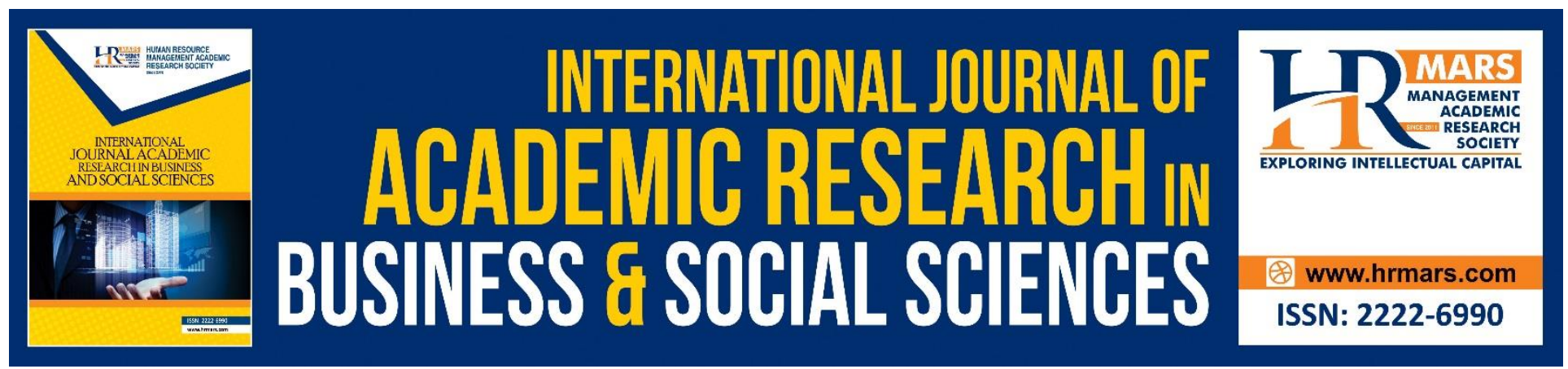

\title{
Analysis of Claim that Wahhabi Group are Anti Mazhab
}

Abd. Rasyid Idris \& Basri Ibrahim

To Link this Article: http://dx.doi.org/10.6007/IJARBSS/v10-i9/7884

DOI:10.6007/IJARBSS/v10-i9/7884

Received: 28 June 2020, Revised: 21 July 2020, Accepted: 19 August 2020

Published Online: 05 September 2020

In-Text Citation: (Idris, \& Ibrahim, 2020)

To Cite this Article: Idris, A. R., \& Ibrahim, B. (2020). Analysis of Claim that Wahhabi Group are Anti Mazhab. International Journal of Academic Research in Business and Social Sciences. 10(9), 912-922.

Copyright: @ 2020 The Author(s)

Published by Human Resource Management Academic Research Society (www.hrmars.com)

This article is published under the Creative Commons Attribution (CC BY 4.0) license. Anyone may reproduce, distribute, translate and create derivative works of this article (for both commercial and non-commercial purposes), subject to full attribution to the original publication and authors. The full terms of this license may be seen

at: http://creativecommons.org/licences/by/4.0/legalcode

\section{Vol. 10, No. 9, 2020, Pg. 912 - 922}

Full Terms \& Conditions of access and use can be found at http://hrmars.com/index.php/pages/detail/publication-ethics 


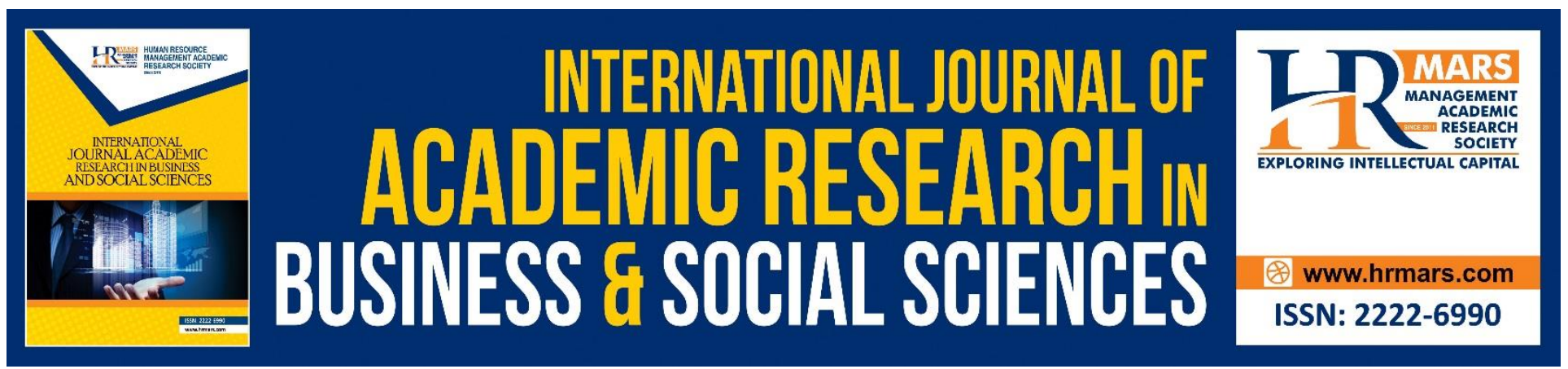

\title{
Analysis of Claim that Wahhabi Group are Anti Mazhab
}

\author{
Abd. Rasyid Idris ${ }^{1} \&$ Basri Ibrahim ${ }^{2}$ \\ ${ }^{1}$ University Islam Malaysia, Cyberjaya, Malaysia, ${ }^{2}$ University Islam Malaysia, Cyberjaya, \\ Malaysia/Faculty of Islamic Contemporary Studies, University Sultan Zainal Abidin, Terengganu, \\ Malaysia. \\ Email: acsid@hotmail.com
}

\begin{abstract}
Wahhabi is a brand referred to a reformative movement in Arabic Peninsula around three centuries ago. In Malaysia specifically, besides the term Wahabi, other term used for this reformative movement is Kaum Muda (Young Community). There are many controversial matters arising among Muslim community related to this movement, as it creates disunity and dispute. Among the accusation directed to this group are not having sect, anti-sect and creating the fifth sect. This causes Muslim community to dissociate and produce a group who do not want to practise ancestors' tradition that has rooted in the community. Therefore, this writing aims to analyse accusation and claim based on the stance presented by the scholars of this Wahhabi movement themselves. Method used in this writing was qualitative method. Data were gathered from document analysis based on books and articles published by the accusing party and the accused side. This study found that the accusation is inaccurate and based on wrong basis. Argument used to obligate every people to have sect needs details and it cannot be exploited blindly. In fact, the argument lining that a person can only hold to a single sect is irrelevant and unrealistic. Practice in various aspects of community's life does come across all sects especially around the four (4) main and renowned Fiqh sect. What stressed by Wahabi scholars is that we should not be fanatic to any sect until turning our back to evidences of al-Quran and sunah.
\end{abstract}

Keywords: Wahhabi, Kaum Muda (Young Community), Sect, ljtihad, Taqlid.

\section{Inroduction}

Many writings have been produced to study the personality and background of Muhammad Bin Abdul Wahhab as the individual who established this movement and stream. The conclusion is obvious that he is a sunni and not Khawarij as claimed by some community. Therefore, the group referred to him are from among Ahli Sunah wa al-Jamaah, not from others. But the usage of this Wahhabi term, it develops from time to time. In context of Malaysia and Archipelago, the label is directed to anyone who opposes local practice. Whoever practises other practice different from sect (Syafi'e in context 
INTERNATIONAL JOURNAL OF ACADEMIC RESEARCH IN BUSINESS AND SOCIAL SCIENCES Vol. 10, No. 9, 2020, E-ISSN: 2222-6990 @ 2020 HRMARS

of Malaysia), he is one of Wahhabi or Kaum Muda. Person like this is accounted as violating ijmak, opposing 'uruf, not respecting scholars and elders, and then considered as anti-sect.

The stand of Wahhabi group unsettles community and arises dispute. Many matters rooted for generations in community are reprimanded, criticised, blamed and eliminated by this Wahhabi group. It becomes a threat to status quo of religious practice among Muslim community in Malaysia. Consequently, the community divides. There are some who still hold to ancestors' tradition and consider it as sect's practice that needs to upheld high. Some group have defied to bind to paradigm of thought that all inherited must always be right. They are also more free and do not want to be bound to view of only one sect. In fact, it is not denied that between the differences, there are still who are more extreme by denying the importance of sect in individual and communal practice.

Briefly, there appears a group obsessed with only one sect which is Syafie in context of Malaysia and a group fighting to free human from the extremism. The first group is referred as following Syafie sect while the second group is labelled as Wahhabi. The question is, is it true that this Wahhabi promote method of practice without any sect? Or it is only a hard reaction to the group that take sect as their shield to continue customs inherited from past ancestors? Sect is exploited as a shield admitting the corruption done by some of community while sect has nothing to do with the matter.

Writings on this Wahabi group is numerous and encompass various branches of issue. Among the classical refrences by opposition of Wahhabi is al-Durar al-Saniyyah fi Rad 'ala al-Wahhabiah (Dahlan, 2003). For works defending Wahabi meanwhile are such as 'Aqidah al-Syeikh Muhammad Bin Abd al-Wahhab al-Salafiyyah wa Atharuha fi al-'Alam al-Islamiy (al-'Abbud, 2000), Athar Harakat Da'wah al-Syeikh Muhammad Bin Abd al-Wahhab fi al-'Alam al-Islami (al-Tamimi, 2006), Tashih Khata' Tarikhiy Hawla al-Wahhabiyyah (Al-Syuwai'ir, 1419H) and many more. For writings touching on question of sect and Wahabi practice in Archipelago there are studies such as Sikap Pengikut Salafi Wahabi di Indonesia Dalam Masalah Khilafiyah (Endang Madali, 2015) and Wahabi!!? Atau Sunah Yang Terlindung (Ahmad, 2009) and some more.

This article is written to prove the stance of Wahabi scholars to practice of sect. Is their claim true that they reject practice of sect or is the claim true that they actually invite human to perform taqlid to them? Through examination to the matter, hopefully this effort will succeed to explain any arising vagueness.

\section{Research Methodology}

This article employed qualitative study for obtainment of findings. Data were processed through analysis of documents found from scholars' writings on Wahhabi either as positive or negative. Besides that, it also benefited question and answer session available in social sites. In context of this article, this qualitative method was applied to understand deeply the argument posed by both differing sides. Next, it was seen in several practices in rules of Stat Islamic Religious Council. Data collected were analysed and elaborated through inductive, deductive and comparative methods to gain appropriate results complying with the lined research objectives. 
INTERNATIONAL JOURNAL OF ACADEMIC RESEARCH IN BUSINESS AND SOCIAL SCIENCES Vol. 10, No. 9, 2020, E-ISSN: 2222-6990 @ 2020 HRMARS

\section{Findings}

The side accusing Wahhabi group as anti-sect or establishing the fifth sect is not true. What fought by them is that a Muslim would not be fanatic to only a certain sect until he turns his back to arguments from al-Quran and authentic and clear hadis. The same thought is actually also found in other scholars not from Wahhabi stream, for example: Dr Muhammad Said Ramadan al-Buti. Thus, this stand is more of respecting all sects compared to being fanatic to only a sect.

\section{Taqlid of Sect or ljtihad?}

Question of whether a person follows sect or not, always revolves around ijtihad and taqlid issue. ljtihad means a striving effort to gain religious law either logically (aqli) or evidently (naqli), which is qat'ie or zanni in the form where the soul feels unable to add it more (al-Kafawi, 1985: 8). While taqlid means "following one's opinion whose words are not religious argument without any argument" (alSyawkani, $1418 \mathrm{H}$ : 860-861). There is another term being in between of ijtihad and taqlid, it is called ittiba'. Ibn Khuwaiz Mindad al-Basri differentiated between ittiba' and taqlid by his words: "taqlid means from religious aspect, referral to a word which its speaker has no argument upon it, this is prohibited in religion. While ittiba' is something convicted upon it with argument" (alFallani,1997:127). Conclusively, the ittiba' happens when a person follows a scholar's opinion by knowing his evidence and argument, while he is accounted of taqlid if his belief is without knowing of its evidence and reference.

\section{Claim that Wahabi are Anti to Sect Practice}

A rumour has spread for a long time that this Wahabi does not like sect. They all for abandonment of the four sects Fiqh books. They prohibit taqlid and obligate ijtihad. Wahabi scholars are more of calling to their opinion compared to holding to sect's opinion. This Wahabi group likes to take the easiest from religious laws and have less passion to practise religion, on account of that there are many practices that they prohibit community from practising them. From a perspective, people who hold to sect's opinion is considerd as ani-sunnah.

For Malik Beh, he claimed that the aim of Wahhabi to do that is to castrate the function of the four sects and ultimately eliminate them. It is for the sake of personal interest which is fame. It also symbolises attitude of not acknowledging others' scholarship. Wahhabi is seen to try diverting public from learning Fiqh knowledge as a path to know Islamic religion and laws of rituals. While the sects were built to explain the contents of al-Quran and hadis of Prophet S.A.W in matters of rituals and transactions. Indeed, not valid our Islam is except by doing taqlid to imams of sect. People who step out from sect is deviated and deviating and might bring to infidelity as taking from Kitab and sunah explicitly is among the elements of infidelity as many from al-Quran and hadis which explicit are clearly infidel. It is also unnecessary to accuse imams of sect of abandoning sunnah while they were knowledgeable, pious, observant and highly concerned of following sunah of Rasulullah S.A.W. This Wahhabi has formed the fifth sects of Islam after the four famous Fiqh sects which are: Maliki, Hanafi, Syafiie and Hanbali (Beh, 1994: 43-45).

\section{Discussion of Issue}

To discuss every accusation in details, it needs a wide space. All matters arised regarding ijtihad and taqlid of sect have been answered. However, to get a clearer picture on the stance of Wahabi in this 
matter, it is necessary to bring forward statements from their figures. From there, it can be evaluated justly of how far the truth of the accusations is.

In this matter, Muhammad bin Abd al-Wahab (MAW) explained in one of his letters to answer the accusation towards him regarding the belief of sect. MAW stressed that he held to Usul Ahli Sunnah Wal Jamaah, while in Fiqah branch, he held to Hanbali sect. He did not deny those who perform taqlid to anyone of the four imams of sect. Therefore, he did not examine others' belief of sect and did not oppose it. Nevertheless, he did not recognise other than Hanafi, Maliki, Syafi'ie and Hanbali sects. This is because for him, sects such as Rafidah, Zaidiah, Imamiyyah and other than them do not possess strong system (al-Sahsawani, n.d: 482).

However, as a person who learns al-Quran, al-hadis and other religious knowledge, he definitely found different opinions with various evidences and arguments. Therefore, when he found that the authentic evidence in his view differs from opinion in Hanbali sect, he will leave the sect's opinion in the matter. He said:

"While our sect is the sect of al-Imam Ahmad Bin Hanbal, imam of Ahli Sunah in matters of branch. We do not claim (for permission) of ijtihad. When it is clear for us an authentic sunah from Rasulullah S.A.W, then we will practise with it. We will not prefer anyone's words over it".

(Ibn-Qasim,1385H.1:289-290)

He also emphasised that the action totally does not mean that he was a mujtahid qualified of forming own's sect. He stressed:

"...We have no right of reaching the level of absolute ijtihad and nobody among us who claim of it. It is only that in several (Fiqh) problems, when it is authentic by our side a clear evidence from Kitab (al-Quran) or sunnah unamended, unspecified and not contradicting to evidence stronger than it and held by one of the four imams of sect, then we take it and leave the sect (Hanbali). For example, inheritance of grandfather and male relatives, truly we prefer grandfather to inherit even though it violates the sect of Hanabilah scholars".

(al-Sahsawani, n.d: 482)

The statements can be understood as he grew up and learnt in the group of family and teaches and community of Hanbali sect. It also pictures that MAW was not strictly bound to Hanbali sect instead he empahised more on the strength of evidence. Therefore, if there is any evidence clearer of its argumentative strength from Hanbali sect, he would hold to that. It is just that the opinion must be in scope of opinion from scholars of the four honourable sect by side of Ahli Sunah wal-Jamaah which are Hanafi, Maliki, Syafi'ie and Hanbali. He believed that it is not an obstacle for a knowledgeable person to perform iijtihad in several Fiqh matters while in doing taqlid to sect inother matters. This has been performed by many scholars among the four sects. They have their own choice of ijtihad differing from respective sect belief (al-Sahsawani.n.d: 482).

After the time of MAW, there is another scholar figure who loudly spoke on Fiqh sects which was Muhammad Rasyid Ridha. He was said to be influenced by Wahabi movement and supported it. He was of Syafi'ie sect, it was just only in several Fiqh problems he did not do taqlid specifically to any particular mujtahid. He only spoke on khilaf problem based on evidence, besides observing the manner to all parties. Despite loudly fighting of ijtihad, however demand for this practice is not to all individuals but only to scholars specialising in syariah (Ridha, 1990. 8: 629). Conclusion of his stance is, having sect is not an obligation. This is because the appearance of sects only happened after generation of Companion and tabi'in. What is obligatory to the community is to follow the opinion of 
INTERNATIONAL JOURNAL OF ACADEMIC RESEARCH IN BUSINESS AND SOCIAL SCIENCES Vol. 10, No. 9, 2020, E-ISSN: 2222-6990 @ 2020 HRMARS

the stronges argument regardless of sect. Therefore, obligating a person to hold to a particular sect is a false action. It is not compulsory to anybody. Supposedly, if there is any clash of opinion, it should be evaluated that what complies with truth should be taken while what violates truth should be left. Matters becoming ijma' of scholars are obligatory of acceptance and they cannot violated. In clashing matters, it is obligatory to arbitrate between book of Allah and Sunah of His Messenger S.A.W (Ridha, 1990. 8: 432). He also called for an agency that that can encompass Muslim community represented by scholars of various sects. Its aim is to produce agreed fatwa as a guidance for this community's practice based on Islamic religion without being divided into sects and schools of thought. What he hoped for has already existed nowadays. There are conferences of Islamic Fiqh discussing on community's matters across ijtihad of pacticular Fiqh sects only. This is to preserve the community's benefit.

Another Wahabi referential figure is Abd Aziz bin Abdullah bin Baz. He held the position of chief mufti of Saudi Arabian government for over 25 years and became the teacher to many later Wahabi scholars. Like Muhammad bin Abd wahab, he was also of Hanbali sect. However, he stressed that his belief was not of taqlid, instead in form following the principles built and held by the sect. In Fiqh problems with clash in them, he was not bound to Hanbali sect but he would revise for opinion which is supported more by evidence. He would produce fatwa by the opinion regardless of whether it complies with Hanbali sect of contradicts it. This is because it is more prioritised of follow the truth than sect's opinion (Ibn Baz, 2020). Regarding the term no sect, he explained that if the term refers to not obligating a particular sect to someone, it is right. Also if it is meant by no obsession or no blind taqlid, the statement is right. But if it means that someone cannot refer himself to any sect, it is wrong. It contradictd with scholars' stand and practice. Despite, what is right is that a person can relate himself to any sect based on his life background and studies with scholars. The relationship like that does not harm as long as it is not a mere taqlid or obsession. So, when the truth is discovered, then he should hold to it even it is not from his sect belief (Ibn Baz,2020).

Other figure regarded as reference for this Wahabi group is Muhammad Nasir al-Din al-Albani. He was raised up by a family of Hanafi sect and learnt Fiqh of Hanafi sect since young. However, when he was adult and dove into this scholarly field, he stressed that there is no evidence prohibiting taqlid, instead taqlid is something needed by those who are ignorant (al-Albani, 2020). But when he rejected harly the obsession of sect until the sect is regarded as religion that cannot be opposed even of a strand of hair. While the action of ittiba' to a scholar whose knowledge is trusted, it is obligatory (alAlbani, 2020). That is his stance on public that do not reach the level of knowledge to understand evidence. However, for the group of higher ability, he regarded the action of taking scholar's opinion as tayammum. In absence of water, tayammum is used. When water is present, then you should return to water. Therefore, if a person has already found evidence of al-Quran and sunnah and words of Companions, it is obligatory to hold onto it and not rejecting by any scholar's words (al-Buti.n.d:3031).

The next figure which is also referred by some who are called Wahabi is Yusuf Al-Qaradawi. In matters of sect, he believes that a person is definitely able of in Fiqh problem taking Maliki's opinion, and in other problem taking Hanafi's opinion, and in other next problem taking Syafi'ie's and next taking Hanbali's. These all according to him are not talfiq as claimed by some later scholars. Instead, 
the prohibited talfiq is when someone mixes scholars' opinion without evidence, it is a mere taqlid or entertainment of desire, not based on which evidence is stronger. What he always calls for is holding to evidence either it agrees with sect or opposes it (al-Qaradawi, 2020). He also fights that scholars should perform ijtihad intiqai'i (performing ijtihad of choosing between different scholars' opinion based on the strongest evidence, argument and benefit). He also demands that scholars always evaluate argument and evidence posed to the community. He lines that the evaluation should be based on the following aspects:

i. The most eligible opinion in our time.

ii. The most emphatic to community.

iii. The closest to religious leniency.

iv. The one that can achieve objectives of religion (maqasid syarak) and human's benefit and prevent harm from them the most.

Thus, a faqih should perform ijtihad revising one of the existing opinions and does not leave the public in puzzle of the solution (al-Qaradawi, 2020).

Besides scholars being related to Wahabi, there are also from among those who are not Wahabi who are almost in agreement in this matter. An example is Muhammad Said Ramadan al-Buti. In this matter, he emphasised that what is said of having sect, does not reach the level of performing ijtihad doing taqlid to sect of mujtahid imam either to only a sect or moving from one sect to another. While the people who have no sect are the public who cannot perform ijtihad but want to do taqlid to any existing Fiqh sects (al-Buti: 11-12). He explained further that a muqallid must follow one of existing mujtahid imams and he owns a right to practise with only a sect and remain with it for his whole life (al-Buti: 23). Therefore, it can be concluded that by his side:

i. People who are unable to take law directly from al-Quran and al-Sunnah must follow one of sect imams who reached the level.

ii. A person can practise by any sect that he wants.

iii. He can also move to other imam if he wants.

\section{Extreme Thought}

In talking about flexibility in sect fought by many scholars, it is undeniable that there is a quite extreme call. For example, what is called for by Muhammad Sultan al-Khajandi as quoted by al-Buti in his work seems to be quite too much. He is said to prohibit people from holding to any sect instead all individuals are demanded to take law by their own by referring to al-Quran and books of hadis. However, the conclusion as in the book Bahaya Anti Mazhab (Mufti Department of Pulau Pinang, 2017) directed to Wahabi group is from the perspective and explanation of al-Buti. It cannot be ascertained that those who quote from al-Buti have really read al-Khajandi's book. If what is pictured is really as it is, then it is an extreme thought that should be avoided. However, if al-Albani's evaluation to the writing is considered, it is not as bad as that. It might be due to the choice of general word while it is directed to a certain group making it extreme and wrong. Al-Albani concluded the writing as (al-Buti, n.d: 10): 
INTERNATIONAL JOURNAL OF ACADEMIC RESEARCH IN BUSINESS AND SOCIAL SCIENCES Vol. 10, No. 9, 2020, E-ISSN: 2222-6990 @ 2020 HRMARS

i. Not defying truth and importance of the sects' existence.

ii. Not defying the authenticity of taqlid for people who do not reach the level of ijtihad qualification. iii. Defying those who are obsessed with sect until abandoning the evidence that he understands.

In context of Archipelago realm, the writing by A. Hasan in Risalah al-Mazhab is strict and invites controversy. If it is directed to all leels of community, the statement is wrong and exaggerated. But observing the background of the writing, it can be seen from a different perspective. A. Hasan was renowned of fighting for freedom from blind taqlid in religion. In fighting of dakwah and reformation pioneered by him, he was famous of being strict and loud in opposing taqlid, and perseverant in defending the strength of ijtihad and intellect in understanding of evidence. This idea was inspired in in his effort of creating awareness, and real understanding of law from freedom intellectual inquiry. It was a reaction to reality of religion at that time which was frozen and full of ignorance. It is the corruption of thought and pessimism patterned by religious personnel to the community, which to be eliminated. This is stressed in his book Risalah al-Mazhab rejecting practice of blind taqlid to sect without clear foundation of evidence.

He definitely encouraged ijtihad, examination of law from al-Quran and sunnah but the call is directed to religious group teaching in religious institution not to public community. He specifically suggested that teachers who can teach Fiqh books of Syafi'ie sect such as: Fathul Qarib and Fathul Mu'in to force their thought and ability of ijtihad. He said:

"Teachers who are already able to teach Fathul Qorib I guarantee they can understand from Quran and Hadith easily. As long as they are hardworking and brave to get rid of taqlid which he did!"

Unfortunately, his suggestion is not entertained by religious teachers as they are more to defend the inherited sect's opinion in the tradition of thought without being ready to evaluate and consider by ijtihad and intellectual strength:".....but due to fear of being called as kaum muda, becoming wahabi group on account of losing influence then kiyais and teachers do not want to change from admitting of holding to Syafi'ie sect falsely"(Amir, 2015).

\section{Perlis the State of Wahabi}

There is official statement from state authorities denying the Wahabi call labelled to the state of Perlis, this includes the speech from DYMM King of Perlis Himself $(\mathrm{BH}, 2018)$. But that is the stigma in the thought of some from community. This is proved in several incidents, among the latest is when Perlis government through Religious Council gazette declared postponement of congregational and Jumaat prayer to constrain the spread of covid-19 outbreak in Perlis state (MAIPs, 2020. 7:77) many say that this is a Wahabi fatwa preventing Muslim community from performing rituals. But after that, one by one state in the whole Malaysia took the same approach after seeking advice from Ministry of Health Malaysia (The Malaysian Insider, 2020). That also goes to Perlis religious authorities produced a permission of performing Jumaat prayer with attendance of not less than three and not more than 12 individuals (MAIPs, 2020. 7:82), many who claim that it is a Wahabi fatwa. But after that one by one state follow the same step (BH (2), 2020). This is the flexibility of sect practised to uphold religion's dignity and protect human's safety. 
INTERNATIONAL JOURNAL OF ACADEMIC RESEARCH IN BUSINESS AND SOCIAL SCIENCES Vol. 10, No. 9, 2020, E-ISSN: 2222-6990 @ 2020 HRMARS

What is the real belief of Perlis government? It can be understood through State Constitution which has been framed since a long time.

\section{Constitution of Perlis State}

Islamic Religion and Malay Customary Council of Perlis (Maips) explains that Ahli al-Sunnah is a group of Muslims holding to al-Quran, Sunnah and opinion of Companions. The council (Maips) is not bound to any particular sect. In any sect in which their opinion is clear and obvious of from Kitab Allah or Sunnah of His Messenger or congregation of companion, they hold to it. While the sects such as Hanafi, Maliki, Syafi'ie and Hanbali in official view of Council are accounted in honourable sects included in the term Ahl al-Sunnah wa al-Jamaah. Maips is really guided by the sects and takes their opinion which is reasoned from al-Quran, sunnah and congregation of Rasulullah S.A.W.'s Companions (Daud, n.d: 138).

Based on this stance, it can be concluded that the source of law applied in decision of fatwa in Perlis are al-Quran, Sunnah and Companions' fatwa according to interpretation and explanation by scholars from various renowned sects. It is not bound to only one sect, instead revision is done based on evidence which is stronger. Perlis also practices all sects and does not restrict to only a sect moreover of rejecting the whole sects. This is proved in the whole fatwas that have been produced by State Fatwa Committee.

This flexibility is religion is also shared by authorities in other states. Perlis which is accused as Wahabi and Johor which is known as anti-Wahabi, both do not restrict to only a sect. Islamic Religious Council of Johor has gazetted in subsection 48(6) Islamic Religious Administration of Johor State Enactment 2003 as follows:

"It is gazetted that Muslim community in the State of Johor must follow Islamic laws and teachings based on Ahlis Sunnah Wal Jama'ah belief, from aspect of faith based on Al-Asyai'rah and Al-Maturidiah sect, Syariah guided by Syafi'e sect. However, the three honourable sects which are Hanafi, Maliki and Hanbali can be referred and implemented in solution of certain problems and from aspect of moral disposition must hold to akhlak Islamiyyah."

(Johor, 2012:892)

Although it is stated that the basis of sect belief in Johor is Syafi'ie, however in solving certain problems needing of holding to other sects, there is flexibility of referring to opinion from other renowned sects.

\section{Conclusion}

Wahabi scholars do not call for freedom from sects. Most of them have held onto sect based on education and system of study undergone. Holding to one of renowned Fiqh sects is the practice of scholars since the past. What fought is that every believer should uphold at high evidences of religion over the believed sect's opinion. If opinion form other sects is more correct and its argument is stronger, he should hold to that and open-heartedly leave the opinion of believed sect. People who abandon religious evidence which argument is authentic for the sake of obsession to sect, actually 
INTERNATIONAL JOURNAL OF ACADEMIC RESEARCH IN BUSINESS AND SOCIAL SCIENCES Vol. 10, No. 9, 2020, E-ISSN: 2222-6990 @ 2020 HRMARS

they have made the sect as their religion. This is the cursed attitude and this is what criticised by Wahabi scholars.

Group of scholars who are able to examine evidence and evaluate argument which is stronger, it is unnecessary for him to do taqlid to others. Those who are able to process argument and evidence must attempt to do ijtihad and explain to community what is seen as true. If there is any difference of opinion between modern scholars and past scholars, it is not necessarily cursed as something made fatwa at a certain time is not necessarily suitable for other time. Something authentic at a time might be voided at other time. This is put by the scholars as a method of: 'Change of fatwa is due to change of place, time and customs" (al-Qaradawi, 2020). ljtihad like this has been performed by scholars of sect for a long time. They should state to the community the authentic argument for related matters besides appreciating community's benefit.

For those who are not scholars but are able to learn religious provisions and evidences, should examine scholars' argument at their ability. Then they should choose stronger opinon, and it is not a fault to leave their sect in several matters and hold strongly in other matters. It depends on level of study. For those who do not possess knowledge ability to understand religious argument and evidence must do taqlid to trusted teacher.

Besides that, it should be reminded that after all these, it is obvious that the accusation that Wahabi are anti-mazhab is incorrect. Instead, they are the one who celebrate opinions from all existing Fiqh sects practise opinion of the strongest argument. Should there is any difference of evaluation, it is a nature that Allah has bestowed upon the whole mankind.

\section{Corresponding Author}

Abd. Rasyid bin Idris, Universiti Islam Malaysia, Cyberjaya, Malaysia.

Email: acsid@hotmail.com

\section{Acknowledgement}

Special thanks to the Majlis Agama Islam Dan Adat Istiadat Melayu Perlis for funding the research under Jamalullail Professorial Chair, Universiti Islam Malaysia.

\section{References}

Al-Albani, M. N. D. (n.d). Kaset Fatwa al-Madinah. (21.2.2020).Al-Albani, M.N.D. (n.d). Kaset Silsilah al-Huda wa al-Nur. (21.2.2020).

Al-'Abbud, S. A. (n.d). 'Aqidah al-Syeikh Muhammad Bin Abd al-Wahhab al-Salafiyyah wa Atharuha fi al-'Alam al-Islami.

Al-Buti, M. S. R. (n.d). amadan. al-Lamdhhabiyyah Akhtaru Bid'atin Tuhaddidu al-Syari'ah alIslamiyya. Maktabah al-Farabi.

Al-Fallani, S. M. M. (1997). aliki, Iqadh Humam Uli al-Absor li al-lqtida' bi Sayyid al-Muhajirin wa alAnsar, Syarjah: Dar al-Fath.

Al-Kafawi, A. B. A. M. (1992). al-Kulliyyat Mu'jam fi al-Mustolahat wa al- Furuq al-Lughawiyyah. Beirut: Mu'assasah al-Risalah.

Al-Qaradawi, Y. A. (n.d). Al-ljtihad al-Intiqa'i. www.al-qaradawi.net (10.5.2020).

Al-Qaradawi, Y. A. (n.d)..Al-ljtihad fi al-Syari'ah al-Islamiyyah. (https://www.al-qaradawi.net $31 / 3 / 2020)$. 
INTERNATIONAL JOURNAL OF ACADEMIC RESEARCH IN BUSINESS AND SOCIAL SCIENCES

Vol. 10, No. 9, 2020, E-ISSN: 2222-6990 @ 2020 HRMARS

Al-Sahsawani, M. B. (n.d). Siyanah al-Insan 'an Waswasah al-Dahlan, $5^{\text {th }}$ Ed., 175, Wakaf Abd Aziz dan Muhammad al-Abd Allah al-Jumaih.

Al-San‘ani, M. I. (1985). Irsyad al-Nuqqad ila Taysir al-ljtihad, Kuwait: Al-Dar al-Salafiyyah.

Al-Syawkani, M. A. (1418H). Irsyad al-Fuhul ila Tahqiq al-Haqq min 'Ulama al-Usul. Edit. Syaaban Muhammad Ismail, Kaherah: Dar al-Salam.

Al-Syuwai'ir, M. S. (1419H). Tashih Khata' Tarikhiy Hawla al-Wahhabiyyah. Jami’ah Islamiyyah bi alMadinah.

Al-Tamimi, A. (2006). Athar Harakat Da'wah al-Syeikh Muhammad Bin Abd al-Wahhab fi al-'Alam alIslami. International Seminar on Muhammad Bin Abd al-Wahhab organised by Perlis State Government on 17 March.

Amir, A. N. (2015). Hasan Bandung: Fikrah dan Perjuangannya, July 4. bharian.com.my.2020.

Dahlan, A. Z. (2003). al-Durar al-Saniyyah fi Radd 'ala al-Wahhabiah. Dar Ghar Hira'-Maktabah alHabib.

Daud, Z. M. (n.d). Ahli Sunnah Perlis Kelahiran dan Perkembangannya. Jurnal Usuluddin.

Endang, M. (2015). Madali, Sikap Pengikut Salafi Wahabi Di Indonesia Dalam Masalah Khilafiyah, Konsentrasi Syariah, Program Doktor Pengkajian Islam, Sekolah Pascasarjana Universitas Islam Negeri (UIN) Syarif Hidayatullah, Jakarta.

Ibn Baz, A. A. A. (binbaz.org.sa 25.2.2020).

Ibn Baz, A. A. A. (maserah.binbaz.org.sa) 29.3.2020.

Ibn Qasim, A. R. M. (1385H). Muhammad, Al-Durar al-Saniyyah fi al-Ajwibah al-Najdiyyah, Beirut: AlMaktab al-Islamiy.

Khairuldin, W. M. K. F. W., Hassan, S. A., Anas, W. N. I. W. N., Mokhtar, W. K. A. W., \& Embong, A. H. (2020). Al-Takyif Al-Fiqhi and its application in Islamic research methodology. Journal of Critical Reviews, 7(7), 462-467.

Ridha, M. R. (1990.) Tafsir al-Manar, Kaherah: al-Hay'ah al-Misriyyah al-'Ammah li al-Kitab. Warta Kerajaan Negeri Johor, page 892, 16 Feb 2012. 